\title{
Tourism and the hospitality industry: current state problems and prospects of development
}

\author{
Irina Buharova ${ }^{1,2}$, and Liliya Vereshchagina ${ }^{1^{*}}$ \\ ${ }^{1}$ Don State Technical University, Gagarin Sq., 1, Rostov-on-Don, 344003, Russia \\ ${ }^{2}$ Rostov Branch of the Russian Customs Academy, 20 Budennovsky Ave., Rostov-on-Don, 344000, \\ Russia
}

\begin{abstract}
The article considers the current trends in the development of the tourism and hospitality industry as the most important ways to develop the geographical, cultural, social and political space. The article analyzes the state support measures for service sector enterprises, as well as the main current problems among tour operators and travel agents, which were identified by the Russian Union of Travel Industry. Recommendations for the development of tourism in the current situation are given, two key trends of the tourism industry for 2021 are analyzed.
\end{abstract}

\section{Introduction}

Today, tourism is one of the most important ways to explore the geographical, cultural, social and political space. Therefore, it makes sense to talk about the geopolitics of tourism as one of the branches of geopolitical science [3].

The geopolitics of tourism studies the following problems.

The impact of international tourist flows on public policy.

The influence of modern geopolitical factors on the development of the tourism industry.

The impact of the sanctions policy on the formation of tourist flows.

The influence of international tourism on socio-cultural and political processes in the world.

The impact of international tourist flows on the sustainable development of society. The movement of people, as it is happening today, turns tourism into a global phenomenon with a clear geopolitical context.

\section{Materials and methods}

According to the latest research by the UN specialized agency, the World Tourism Organization (UNWTO), the growth of international tourist arrivals outpaced the growth of the economy as a whole.

International tourist flows around the world increased by $4 \%$ in 2019 and reached 1.5 billion euros. a person all over the world. 2019 was another year of strong growth, albeit

\footnotetext{
* Corresponding author: vereshagina.lil@mail.ru
} 
slower than the exceptional rates of $2017(+6 \%)$ and $2018(+6 \%)$. The United States led the growth in absolute terms. Based on current trends, the economic outlook, and the confidence index, UNWTO projected a $3 \%$ to $4 \%$ increase in international tourist arrivals worldwide in 2020. [7]

The geopolitical impact of tourism is mainly reflected in the economic contribution of tourism. Problems in the tourism industry affect the level of unemployment, the standard of living, especially in countries where tourism is the leading industry [13]. To the unique geopolitical influence is added the totality of the economic, social and cultural influences of tourism.

The tourism and hospitality industry, given its significant impact on the economic and social development of the country and the branching of economic ties, needs regulation and support from the state. The transition to market relations and fierce competition require the solution of new problems related to the need for an adequate response of the state to significant changes in the external and internal environment of the functioning of organizations of the tourist and hotel complex [6].

In these circumstances, the state takes certain measures to provide economic support to enterprises and organizations in the field of tourism and hospitality [10]. In particular, to support the tourism industry in connection with the spread of the coronavirus in 2020, the amount of the annual contribution to the reserve fund of the Association of Tour Operators (intended for emergency assistance to tourists outside Russia) in the field of outbound tourism ("Tourist Assistance") will be reduced.

The amount of the contribution to this fund for tour operators will be 1 RUB in 2020 [5].

Also, at the initiative of the Ministry of Economic Development, the losses of tour operators on air transportation will be compensated at non-refundable tariffs for the period from January 24 to March 30, 2020 [11]. In addition, tour operators will receive subsidies for the costs of paying for return flights when exporting Russian tourists within two weeks after the" closure " of countries due to the spread of coronavirus. Due to these subsidies, tour operators will potentially be able to speed up the return of funds to tourists [4].

It should be noted that tour operators are required to fully refund tourists for paid tours during the official "closure" of countries for epidemiological reasons. However, the tour operators themselves usually can not receive their deposits from the airlines as part of the tourist product for paid, but not issued transport. It turns out a vicious circle: the law obliges tour operators to return money from tourists for the above reason, but tour operators do not receive money from carriers, since this issue is not regulated by federal law, but only by contractual relations between carriers and tour operators.

Against the background of the unstable economic situation, the Ministry of Economic Development introduces a delay in the collection of tax payments for organizations in the field of tourism (tour operators and travel agents, hotels, organizations that provide tourist services, as well as organizations that classify beaches and ski slopes). The state should also support travel companies by reducing insurance premiums by $30-15 \%$ and taking measures to reduce the tax burden.

In Moscow, the city authorities have introduced anti-crisis measures to support tourism and hotel business, which will suffer from the introduction of restrictive measures due to the unfavorable epidemiological situation [12]. In particular, the corporate property tax extends the deadline for payment of advance payments for the first quarter of 2020, and the property tax-until December 31,2020, as well as enterprises and organizations that lease non-residential facilities and land plots to the city will receive a deferral on payment of rent for April, May and June. 


\section{Results and discussion}

Let's consider the main current problems among tour operators and travel agents, which were identified by the Russian Union of the Travel Industry.

In the field of hospitality, the situation is very difficult, not only in Moscow and St. Petersburg, but also throughout the country. The fee for hotels in Moscow and St. Petersburg has decreased by about $70 \%$ and is in the range of $10-15 \%$. In this situation, hotels are forced to reduce costs in various ways, even resorting to the preservation (decommissioning) of their rooms, reducing working hours and reducing shifts. In the best position are the hotels of the Crimea and the Krasnodar Territory.

In the conditions of restrictions on movement and cancellation of various events in our country, an extreme drop in hotel occupancy was recorded to almost zero in the time interval from spring to summer. In these conditions, after the gradual removal of restrictions imposed due to the unfavorable epidemiological situation, enterprises and organizations of the tourist and hotel complex should, in our opinion, not only optimize their costs, but also purposefully use modern methods and approaches to ensure the highquality operation of tourist and hotel complex facilities. First of all, they should be based on the principles of a systematic approach and process-technological activity, since one of the guarantees of the quality of services in the tourist and hotel complex is the development and implementation of a quality management system at the enterprises of the tourist and hotel industry [2].

In the context of the crisis, which in its scale, apparently, promises to be much larger than the crisis of 2014, it is advisable, in our opinion, to additionally use the following measures to support domestic tourism in our country.

The main problems identified by travel agents and tour operators in 2020 [1]:

1. Tour operators force agents and tourists to reschedule travel dates, change destinations, and do not refund money for tours.

2. Tour operators do not meet the deadlines for responding to requests for cancellation of reservations and claims of travel agents, often in the complete absence of feedback.

3. Tourists threaten the courts, intending to return not only the cost of the tour, but also to compensate for moral damage.

4. Complaints about the explanations of the executive authorities, which assure tourists that they should be returned in full all funds when canceling tours to any country-regardless of whether it is included in the list of not recommended for visiting, or air traffic is stopped in it.

5. The mechanism of reimbursement and postponement of visits, proper registration of documents.

6. Is it legal to freeze funds for deferred visits? What to do if the tour operator will not be able to fulfill its obligations under the contracts in the future.

7. Business support applications are tax breaks, benefits, and flexibilities. Feelings of panic due to the fact that there is nothing to pay the salary, there is no money for rent.

8. Many questions about forecasts - how long can the current situation last? Some see the only way out for themselves - to close down.

9. Russian airlines and railways withhold service fees when returning tickets.

10. Lack of operational communication with the authorities and other organizations that could give clear instructions and provide legal support.

11. Non-return of funds by foreign service providers - hotels, host companies, etc.

12. Non-return of funds from service providers in Russia-museums, parks and other exhibition facilities, exhibition centers, transport companies.

13. Evacuation of tourists in Russia.

14. We need tax holidays, long-term tax benefits. 
15. Issues of state support for the tourism industry in a crisis - will the state take measures to save it?

16. The Russian Union of Tourism Industry is requested to facilitate amendments to the industry law, in particular to Article 14.

17. Partners and host companies do not always reschedule travel dates, even if tourists agree, impose fines, despite recommendations not to visit a particular country.

18. Travel agencies and tourists demand a $100 \%$ refund of the cost of the visit, often referring to incompetent media.

19. Resentment of employees who have been reduced in salary, sent on vacation at their own expense, are offered to leave at their own request.

20. The absence of a single refund policy for tour operators, which would avoid unrest among travel agents.

We believe that it is necessary, in addition to the measures announced by the Ministry of Economic Development, to support tour operators developing tourist products on priority tourist routes, as well as to subsidize domestic transportation by various modes of transport after reducing the epidemiological tension in the tourist market.

The crisis in the tourist market in 2014 was caused by a number of factors, among which it should be noted the introduction of economic sanctions against our country due to the annexation of the Crimea, as well as due to the decline in the price of the ruble, which devalued twice in the fall of 2014 compared to the spring of 2014, In these conditions, leading tour operators reduced the offer of their tourist services on the market by an average of $25 \%$ before the holidays. In 2014, about 20 major travel agencies went bankrupt. Thanks to the insurance of professional liability of tour operators, the affected tourists received compensation from insurance companies, with which tour operators are required by law to conclude contracts of liability insurance to tourists for non-performance or improper performance of their obligations under the contract of purchase and sale of tourist products [8].

In addition, at that time, thanks to the Association of Tour Operators in the field of Outbound Tourism "Turpomosch", our tourists were evacuated from abroad in connection with the mass bankruptcy of domestic tour operators. In 2014, it became possible to rely on the development of domestic and inbound tourism, on the so-called import substitution in the field of tourism and hospitality. The Coordination Council for the Development of Children's Tourism and the Coordination Council for the Development of Domestic and Inbound Tourism have been established under the Government of the Russian Federation. Tourists began to visit not only the Krasnodar Territory, but also the Crimea. Then there was the closure of Egypt and Turkey for our tourists. The domestic tourist flow has increased while maintaining the existing problems at the service level: the lack of an allinclusive service system in the resorts, the high level of prices and the state of the tourist and hotel infrastructure.

It was necessary to solve the problems of promoting the brand of our country abroad. In this sense, the situation in which our country has spent on promoting its brand abroad suggests that Turkey has spent only on its promotion in our market.

The Winter Olympics in Sochi (2014) and the FIFA World Cup (2018) showed the world that Russia, despite all the existing problems, is able to organize and hold large-scale sports events that can be visited by millions of fans and tourists. The stereotype that it is unsafe in our country, there is no infrastructure and normal service, has been overcome. According to experts, successful sports events will have a delayed demand when tourists from abroad visit our country for tourist purposes.

Before the Winter Olympics and the World Cup, a law was promulgated requiring all hotels in the cities that hosted these sports events to undergo mandatory classification, that is, to confirm the level of their service and compliance with the specified "Star"level. Then 
the classification of hotels became mandatory for all hotels in our country. The classification process is expected to be completed in 2021.

But the crisis that hit tourism in early 2020 is truly global and affects many countries around the world. The tourism and hospitality industry, along with other sectors of the economy, needs state assistance not only economic, but also social [15]. In our country, it is necessary to expand the regulatory regulation of tourism, taking into account the adjustment of relations between all participants who form, promote and sell a tourist product [14].

Russia-due to the pandemic and the almost complete closure of its external bordersreceived a powerful incentive for the development of domestic tourism in 2020. Now our country is among the five leaders of the Eurasian region in the restoration of internal transport. In 2021, according to unofficial forecasts of the Ministry of Transport, Russian airlines will increase the volume of air traffic by more than $50 \%$, exceeding - with a favorable development of the situation - the record figure of 2019.

According to Rosstat, in January - September 2020, the fleet of hotel rooms in Russia increased by almost 6,000 units, which is not so far behind the figures for the same period in 2019 (7331 places). In February 2021, the government approved a program of preferential loans for the construction of hotels and other tourist infrastructure. Fig. 1 how the activity of tenants in the section of short-term rent "Avito" has changed. This action and subsequent events will be part of the new National project "Tourism and Hospitality Industry", which is currently being developed. The estimated budget of the new national project is 629 billion rubles. The most important part is the creation of a" high - quality diversified tourist product" on the territory of the country, among the main goals-doubling the number of Russians vacationing in sanatoriums and dispensaries, and tripling the number of their domestic trips [6].

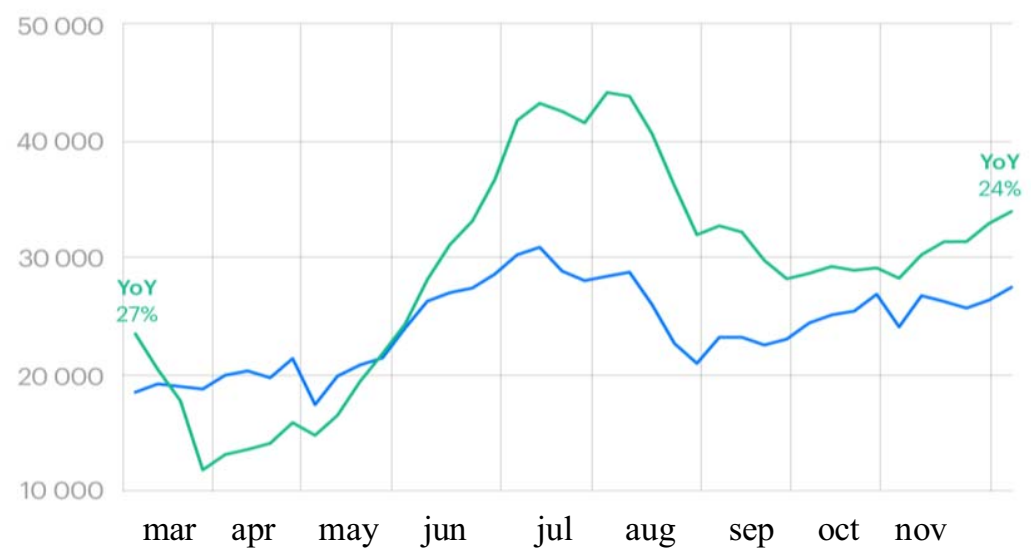

Fig. 1. The activity of tenants in the section of short-term rent "Avito" has changed: - 2020 year, - 2019 year. Source: "Avito".

The main problem: how to" build up " additional tourism potential in the existing infrastructure base of the regions and where to find the necessary resources not only for the creation of new accommodation facilities, but also for the development of centers of attraction in cities and regions, not to mention the renewal and construction of new engineering and technical networks.

The development of the tourism industry in Russia is gaining great importance every year, as it has a stimulating effect on other sectors of the economy, attracts and motivates sources of investment at any level, creates a significant number of jobs, increases the tax 
base, preserves the cultural and historical potential of the country, and promotes the development of interethnic and intercultural dialogue [9].

Let's name two key trends in the travel industry for 2021.

The first is a fundamental redistribution of tourist flows. Previously, hundreds of thousands of people went to the same major cities. They chose the most popular tourist destinations and visited the most popular attractions. And as a result, it turned out that a large number of people were concentrated in a very small area. Since most people can't fly right now and don't want to stand in queues and crowds (mostly for safety reasons), they "disperse". People go to small localities.

But they do not go to any one city, so the number of destinations has increased significantly.

The second trend is blurring the line between everyday life and travel. If earlier people lived in one place and only occasionally went on vacation or on business, now the situation has changed. "They leave their permanent residence and rent a house somewhere else. Sometimes they are residents of cities who want to spend time in nature. Or students who are still unable to return to the dorms, but do not want to live with their parents, so they rent housing with friends in some other city. The period of stay increases to a week, a month, even two months. This is a completely new trend that did not exist before the pandemic.

For this reason, opposite trends are observed in Russia. The pandemic has led to the redistribution of tourism, and to the overload of the most famous resort centers like the Crimea and Sochi. As for the second trend, many residents of Russia, who previously sought to earn money in large cities, were forced to return to their regions in 2020 due to a decline in business activity. And if they do move - it's to the country. Their movements have very little to do with tourism.

For this reason, one of the objectives of the Tourism Development Strategy until 2035 is to stimulate demand and increase the availability of the tourist product of the Russian Federation in the domestic and foreign markets. Interest in domestic tourism in Russia is growing:

The Russian domestic tourism market is changing under the influence of the pandemic and related restrictions. Outbound tourism is being replaced by local tourism: local tour operators invite tourists to the regions, and the sights of Russia are positioned as in no way inferior to foreign ones.

The comparative underdevelopment of domestic tourism in Russia compared to European countries leaves the potential for big changes. At the same time, Russians are characterized by low tourist activity. There is a need to increase demand in the domestic tourism market, as well as to identify the most interesting and promising tourist sites within the country.

The leaders among the tourist attractions of the Russian regions are the Valley of Geysers (Kamchatka Territory), the Big Yashaltinskoye Lake (Republic of Kalmykia), the Dusse-Alin Mountain Range (Khabarovsk Territory), and the Lena Pillars (Republic of Sakha). The list of the TOP 15 attractions is shown in the table below. The full list and text of the analytical guide will be published in the spring on the website nafi.ru in the format of a separate brochure.

Also popular destinations for Russians and foreign tourists are: Moscow, St. Petersburg, Krasnodar Territory, Crimea, Caucasian Mineral Waters, Kaliningrad region with Baltic beaches, Karelia, Caucasus, Baikal, Kamchatka, Altai (price increase by $10-15 \%$, the number of tourists up to $30 \%$ compared to 2020 )

The national project "Tourism and Hotel Industry" aims to increase the number of trips to 140 million per year and the number of employees in the industry to 5 million. 
For the development of domestic tourism, it is necessary to develop tourist clusters with affordable accommodation facilities, restaurants, cafes, recreation and entertainment centers, as well as sports events for various categories of travelers.

The availability of various tourist services (transport, hotels, destinations, etc.) on the Internet and on mobile devices has increased.

The development of the following areas in tourism is promising: sports tourism, gastronomic festivals, small business events, medical tourism, agro-and ecotourism, space tourism and cruises. Requires a high level of online services, sales automation, contactless service. Residents of large cities have a desire to travel on weekends by private transport, with friends or family, it is important to change places and frequency of trips, to get new impressions.

For the generation of $50+$ and citizens with limited mobility, there is an urgent need for the development of medical and health tourism, rural tourism and the creation of ecological roads, the formation of small accommodation facilities and country hotels.

Significantly increases the duration of trips, combining business and leisure, facilitates the transition to remote work. It is necessary to create an opportunity for tourists to travel for a long time and work away from home, observing increased security measures.

When choosing a holiday destination, a tourist is interested in: at the level of logistics accessibility, telecommunications, connectivity of territories, the availability of public catering, rental and service points. It is important to understand what is the greatest value of travel, to form a competitive tourist product, to organize the expected service.

When promoting tourist services, it is necessary to convey the historical value of the territory of the region, to reveal the natural and climatic potential, the availability of transport and the cost of costs; to offer accommodation and food, access to events on the territory; to use visual techniques that evoke desire and vivid emotions long before the trip. It is also important to get feedback from travelers, assess their satisfaction with the quality of services, create discussion forums for travelers on social networks to consult and share their experiences, as well as attract tourists to solve common problems. The concept of sustainable regional development is being actively developed: corporate social responsibility, reduction of harmful emissions into the atmosphere, rational use of all resources, waste recycling, transition to a green economy, participation of small and medium-sized enterprises in solving environmental problems, investment in the development of intelligent technologies; participation of tourists in environmental and natural resources protection activities.

The need for continuous professional development of personnel in the field of tourism and hospitality is formed, in accordance with the constant changes in the requirements of the enterprise, by the organization of digital centers for advanced training.

In order to support and develop domestic tourism, the third stage of the Rostourism program has been launched, aimed at stimulating citizens to rest in the regions of Russia, which allows increasing the demand for travel and accommodation in the listed hotels in the regions of Russia by reimbursing 20,000 rubles in the amount of the ticket purchase.

The summer of 2020 revealed many other problems, among which we note, first of all, shortcomings in service and inflated prices - this traditionally hinders the development of domestic tourism in Russia, and in 2020 these issues were particularly acute. Russian resorts, which this year experienced a heavy load due to the fact that beach holidays abroad were not available, received a lot of negativity in their address. Reasons: restart of infrastructure, lack of staff in hotels due to the uncertainty of the restart of the season, high prices for accommodation, low level of service. To this is often added the poor quality of food: both food and cooking. The elimination of these problems is very important because everyone is interested in the fact that in the coming seasons the Black Sea resorts will be in demand again, and not because of the pandemic. 


\section{Conclusion}

Thus, summing up the conclusions on the problems outlined in the article, we note that it is absolutely certain that in 2020 tourism suffered significant losses-the world tourist flow decreased by 900 million people. As you know, when the demand for goods and services decreases, the supply also decreases. This year, the tourism industry has felt the full charm of the crisis like no other.

For clarity, we will describe an ordinary trip to Turkey. To buy an all-inclusive package at a hotel, you need to contact a travel agency in the spring, and maybe even earlier. By that time, the tour operator had already taken over the prepayment of hotels and airlines. Just then, the hotels began to prepare for the new season - they carried out repairs, hired the necessary staff, signed contracts with bus companies and suppliers of products.

Such a system has been working for many years, but in 2020 there was a coronavirus, because of which a state of uncertainty hangs in the air and does not allow tourists to plan their vacation much in advance-now the decision to leave is made at the last moment.

Many representatives of the tourism sector note that the "coronavirus" restrictions will affect income for a long time. According to experts, the full recovery of the tourism industry may take years, and new rules and medical documents required to visit countries may be introduced to open the borders, and it is likely that people will remain suspicious for a long time about the likelihood of getting infected during the trip.

It is obvious that the virus will not disappear, so sooner or later the entire population of the planet will be forced to learn to live with it. However, we can not say that tourism is waiting for a complete collapse. People will continue to go on vacation, which means that travel agencies will not be left without work, although the requests of tourists will change slightly. Short trips over short distances, as well as a combination of work and leisure, are now very popular. Tourists choose vacation spots near the house, accessible by car, and book accommodation that provides a place of work. At the same time, only a third of the planned business trips took place in the business tourism segment in 2020. There is an explanation for this - thanks to the format of remote work, people can afford to travel without waiting for the holidays.

Paradoxically, the year 2020 in Russia really became the year of the heyday of domestic tourism.

Let's pay attention to the following options for the development of domestic tourism. First of all, next year the therapeutic vacation will be very popular. And not only in the usual resorts of the Crimea, Krasnodar Territory and, but also in the Altai, Belokurikha, Karelia, Bashkiria. Secondly, tourists have requests for ethnic and esoteric recreation-to purify the soul and body after the epidemic. Third, a high level of service is always appreciated.

At the same time, price increases are also inevitable: the cost of living is expected to increase by an average of $20 \%$, which will allow the owners of accommodation facilities to recover losses by 2020 .

Since the borders are still closed and there is no hope for their rapid opening, tourists will choose domestic resorts that will help domestic tourism not only take advantage of the growing demand, but also show their best side, dispel stereotypes and gain a good reputation at a time when air links with all countries will be restored.

We believe that it is necessary to build such a connection with guests that will allow you to collect prompt feedback, solving all the questions and problems that arise from the guest during his stay at your hotel, without being too intrusive.

It is important to understand that we are in a new reality and how" worked for years " can now manifest itself in a completely new way. And it is necessary to be ready to meet the new needs and desires of the guests: from organizing activities that protect them from 
the coronavirus, to more general procedures, with care for a completely safe and clean environment.

Make the information available to the public and bring it to the attention of visitors. After all, the enormous efforts aimed at ensuring the safety of the guest can be left without proper attention.

Technology. Rooms and public spaces should be equipped with disinfection products with appropriate instructions for use, if the guest himself is involved in this process.

Communication - how to get (correct) information. Chat services, whether automatic (chatbots) or not (instant messaging with staff, for example, via WhatsApp), allow you to transmit information to guests faster and more accurately.

If a hotel has an app, it should contain all the protocols and standards for cleaning, surface treatment, disinfection, and monitoring the condition of guests and staff (special attention should be paid to F\&B-Food \& Beverage-services in this matter).

Marketing communications. There is nothing worse than making an effort and investing money if the guest doesn't know what was actually done.

Create unique experiences. Not just the accommodation of the tourist, but the creation of impressions has always been an important part of hospitality. Focusing on the needs and desires of the guest, as well as the appropriate adaptation of the services provided — this is what can be the difference between you and other hotels.

In the conditions of increased anxiety of guests and limited tourist opportunities, during the period of border closure and lack of choice, the guest very acutely feels the lack of personalized service, impressions and joyful events. In addition to making sure that his trip goes smoothly and safely, it is important to give him something that will fill him with a lot of pleasant events.

\section{References}

1. The PCT hotline has identified the top 10 problems of travel agents and tour operators, URL: https:// ratanews.ru/news/news_25032020_5.stm free.

2. S. V. Dusenko, Sustainable development of the economy: state, problems, prospects (PolesGU, Pinsk, 2017)

3. I. F. Ignatieva, Society. Wednesday. Development, 1(26), 111-115 (2013)

4. The Ministry of Economic Development proposes to subsidize the losses of tour operators in connection with the coronavirus (2020), URL: https://www.economy.gov.ru/material/news/ekonomika_bez_virusa

5. Order of the Government of the Russian Federation, 660-r (2020), URL: https:// www.garant.ru/hotlaw/federal/1332696/.

6. Tourism in Russia (2021), URL https://events.vedomosti.ru/events/turizm21

7. World Tourism Barometer, 18 (2020), URL: https://www.unwto.org/world-tourismbarometern 18-january.

8. I. V. Bukharova, L. N. Vereshchagina, Legal order and legal values, 116-121 (2020)

9. S. Rybak, I. Krygina, E3S Web of Conferences, 210, 18039 (2020), DOI: doi.org/10.1051/e3sconf/202021018039

10. T. A. Skvortsova, T. A. Pasikova, L. N. Vereshchagina, A. N. Pozdnishov, A. V. Sukhovenko, International Journal of Economics \& Business Administration, 8(4), 828-837 (2020)

11. V. M. Matvienko, M.B. Smolenskiy, Sociology of passenger and baggage transportation by road: civil law aspect, 146-150 (2020) 
12. M. V. Alekseeva, Yu. I. Isakova, State administration in the information sphere at the present stage, 12-18 (2020)

13. M. B. Smolenskiy, Science and Education: Economy and Economics; Entrepreneurship; Law and Management, 3(130), 92-97 (2021)

14. G. E. Ekinil, A. S. Petrenko, V. V. Provotorina, Hotel service (2021)

15. K. V. Barsukova, V. S. Akhmedova, Strategic regional development in the new economic realities, 13-17 (Lipetsk, 2021) 